\title{
Kerkorde en herderlike sorg - Artikel 51 van die kerkorde van die Nederduitse Gereformeerde Kerk van 2015
}

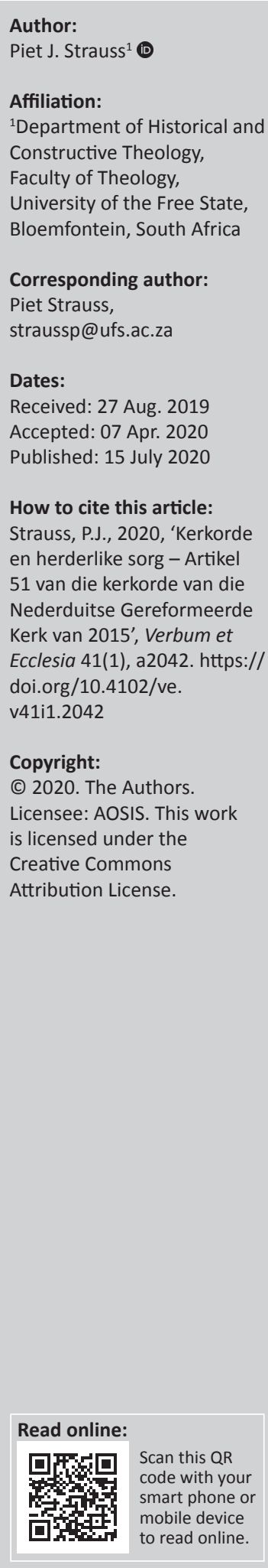

Church order and pastoral care as in article 51 of the church order of the Dutch Reformed Church. The Dutch Reformed Church (DRC) finds its historical roots in the Reformed Church in the Netherlands of the 16th and 17th century. The so-called individual or family-oriented visitation of members by office bearers in congregations in reformed churches dates to the Reformer John Calvin (1509-1564). In recent copies of the church order of the DRC this visitation of members, the elderly, the sick and people in need, as well as the involvement of presbyteries in the weddings and funerals of members, is taken up in an article under the heading 'Pastoral care'. According to the General Synod of the DRC, who is responsible for the church order, pastoral care and visitation by office bearers of church members are core factors in the work or service of the church. Unlike other reformed churches with a link to the reformed Netherlands, the DRC does not limit visitation and pastoral care to the ministers and elders but sees it as an important duty of all office bearers. The implication is that pastoral care should be determined by the Word of God. Using the Word in this regard by all offices in all situations of need requires a pastoral approach.

Intradisciplinary and/or interdisciplinary implications: This article stems from a church and church order of pastoral care in the church. The Church order does not regulate the content of, for example, home visits, sick visits, or marriage counseling, but provides orderly channels through which these matters can flow into the church. Linked to understanding the content or nature of pastoral care, Church Polity, Pastorate and Dogmatics (church concept) can come in handy.

Keywords: responsibility of elders; pastoral care by offices; church order of DRC and visitation; few changes in church order of DRC; pastoral care in visitation, marriages and funerals.

\section{Inleiding}

In sy vierde boek in 'n reeks oor Gereformeerde Kerkreg begin Kleynhans sy hoofstuk oor herderlike sorg, vir hom 'n sleutelaspek van die taak van die kerk, met'n aanhaling van Pellisier (Kleynhans 1988:105). Volgens Kleynhans beskou Pellisier huisbesoek as 'n 'ampsverpligting' van die kerk. Dit is 'die eerste, die mees voor die handliggende en die mees direkte wyse om van aangesig tot aangesig met die kudde van die Here kennis te maak' (Kleynhans 1988:105) en hulle geestelik te versorg. Wat Pellisier betref, het die Here Jesus vir sy kerk voorbeelde hiervan gegee. Hy wys op die gesprek van Christus met die Samaritaanse vrou by die put van Sigar wat haar tot selfontdekking gelei het. Vir hom is dit huisbesoek in die ware sin van die woord. As Maria in die huis van Martha aan die voete van die Here Jesus sit en na sy woorde luister, is dit'n heerlike vorm van huisbesoek ...

Kleynhans wys op Paulus se stelling aan die ouderlinge van Efese op die strand van Milete as hy hulle daaraan herinner dat hy vir hulle in die openbaar gepreek én in hulle huise onderrig het. 'Soos wagters (die amptelike Afrikaanse vertaling van 1953 praat van herders) 'n kudde versorg, so moet julle die gemeente van God versorg' (Hand 20:20, 28). Petrus dring as 'n 'mede-ouderling' by die hulle daarop aan om die kudde van God wat aan hulle (deur die Here) toevertrou is, goed op te pas. Die opdrag om die herderlike staf ten opsigte van die kudde van God op te neem, is van die Here self afkomstig 1 Petrus 5:

Hou toesig oor hulle, nie uit dwang nie, maar gewillig soos die Here dit verwag; nie om eie gewin nie, maar uit toegewydheid; ook nie deur baas te speel oor dié wat God aan julle sorg toevertrou het nie, maar deur' $n$ voorbeeld vir die kudde te wees ... (vv.1-3) 
Hiermee vat Kleynhans die spoor van Bouwman, wat sonder baie woorde en gegrond op Johannes 10 prontuit sê (Bouwman 1985):

Het huisbezoek is gegrond in de Heilige Schrift. Christus is de goede Herder, die de schapen zeiner kudde weidt en verzorg, die zijn leven geeft voor de schapen, die hen bewaard voor het verderf. (p. 556)

Wat Bouwman, Pellisier en Kleynhans betref, word herderlike sorg as 'n ampstaak deur die Skrif aan die ouderling toevertrou. Die ouderlinge as herders moet die kudde in die spore van die Woord lei en bewaar van die kwade en verderf. Vanuit sy Dordts-gereformeerde benadering sê Bouwman dat 'de Gereformeerden' van die begin af die noodsaaklikheid van huisbesoek beklemtoon het. Die Woord moes - naas die verkondiging daarvan in die samekoms van die gemeente ook in die blyplekke van die kudde gebring word sodat die gemeente sy heiligheid in Christus of om Christus ontwil in praktyk kon toon en lidmate hulle na die orde en tug van die kerk kon skik. Herderlike sorg deur huisbesoek is dus 'n verlenging en verindiwidualisering van die verkondiging van die Woord en afgestem op 'n lewe van gehoorsaamheid aan God deur die kudde. Die ampte - veral die ouderlinge moes toesig hou en as herders toesien dat lidmate hulle lewens volgens die Bybel inrig (Bouwman 1985:556).

Daarmee, so lui Bouwman se argument, word nie gesê dat huisbesoek nie die taak van die predikant is nie. Die predikant is ook 'n opsiener of herder van die gemeente (Hand 20:20-21). 'n Herder wat omrede sy kerklike toelating deur Woordonderrig die kudde saam en indiwidueel versorg. Daarom het die Dordtse Kerkorde van 1619 (DKO 1619) artikel 16 bepaal dat die bedienaar van die Woord primêr die Woord en die sakramente - laasgenoemde as 'n amptelike, sigbare verkondiging van die Woord (Strauss 2010:97-100) moet bedien, voorgaan in gebede én toesig hou oor medeampsdraers sowel as die gemeente (DKO 1619, teks in Biesterveld \& Kuyper 1905:230). Juis omdat die bedienaars lerende ouderlinge is, moet hullle met die Woord as gids én herderstaf die gemeentes geestelik versorg. As herders en leraars is hulle tot 'n Skriftuurlike versorging van die kudde geroep. Bouwman koppel hierdie kant van die taak of amp van die predikant aan voorbeelde en opdragte uit die Woord en DKO 1619 artikel 16 én wys daarop dat die Friese Sinode van 1652 in die Gereformeerde Kerk in Nederland - reeds in 'onze' Jan van Riebeeck se tyd! - besluit het: '...predicanten syn censurabel, die de visitatien van hare gemeente versuymen en verlaten'. Hoewel die DKO huisbesoek nie in detail reël nie, was Nederlandse gereformeerdes ernstig op die huisbesoek van die predikant ingestel. Vir baie van hulle was die nalaat van huisbesoek deur die pastor 'ampsversuim' en ampsversuim tugwaardig (Bouwman 1985:557; vgl. Jansen 1952:75-76).

Bouwman oordeel tereg dat die predikant en ouderlinge die regering en versorging van die gemeente as herders saam behartig. Die gemeente word deur hulle gemeenskaplike arbeid opgebou. Daarvoor is:

[h] et huisbezoek ... zoo goed en zoo nodig, niet alleen voor de gemeente, maar ook voor den dienaar des Woords. De band tusschen herder en kudde word bewaard en gesterkt. De herder leert de behoefte der schapen kennen. Hij kan nagaan of de prediking de gewenschte vruchten oplevert, op welke zaken hij zelf in de prediking en bij het onderwijs moet letten. Hij leert naast menige droeve ervaring ook kennen de kostelijke blijken van Gods genade in het leven en de ervaringen van Gods volk, zoodat het huisbezoek ook voor hem zelven rijke vruchten draagt, zoowel voor de verdieping van eigen geestelijk leven als voor zijnen ambtelijken dienst. (Bouwman 1985:489)

Teen hierdie agtergrond en met die stelling van een van die outeurs van die Kerkorde van die eerste Algemene Sinode van die Nederduitse Gereformeerde Kerk (NGK) in 1962 (afgekort as NGKO 1962), J.D. Vorster (Langner 2007:87), ${ }^{1}$ in gedagte, word NGKO artikel 51 (NGKO 2015:15 bevat steeds NGKO 1962 artikel 51, maar in verwerkte vorm, volgens NGKO 1964:11) oor amptelike herderlike versorging in die NGK in hierdie artikel ontleed. Vorster het na NGKO 1962 verwys as die DKO aangepas by die eise van die dag (Vorster 1960:13,14). Vrae wat hierin ondersoek word, is: wat was die historiese aanloop tot NGKO 2015 artikel 51? Wat sê hierdie artikel vir die kerklike ampte en watter sake kan in NGKO 2015, as 'n gereformeerde kerkorde, so bly staan? Wat het 'n gereformeerde kerkorde om oor so 'n saak aan te bied?

\section{Kerkordelike ontstaanswêreld van die Kerkorde van die NGK artikel 51}

Daar is reeds op Skriftuurlike aanwysings vir herderlike sorg en daaruit vloeiend huisbesoek of besoeke aan alle lidmate in hulle leefwêreld, gewys. Veral die predikant en ouderling maar ook die diakens in hulle barmhartigheidstaak - moet as herders die kudde versorg en daarin aan indiwiduele lidmate alleen of sy/haar huismense of gesinne aandag gee. Die beginsel dat die amp van die ouderling primêr koninklik, dié van die predikant primêr profeties en dié van die diaken primêr priesterlik is, isoleer die amp nie van die ander ampte of bedieninge nie. Die optrede van die diaken kan in 'n situasie ook 'n koninklike, profetiese of herderlike kant openbaar.

Die herderlike sorg van NGKO artikel 51 het 'n historiese aanloop onder gereformeerdes. In sy Geneefse Kerkorde of Ordonnances Ecclesiatiques van 1561, 'n opvolger van sy Kerkorde van 1537, bepaal Calvyn in artikel 34 dat die kerklike visitatore wat die Geneefse gemeentes besoek, moet vasstel of die dienaar van die Woord nie net sy verkondiging met sorg hanteer nie, maar ook sy besoek van siekes, sy vermaning van enkelinge wat dit nodig het en sy oplettendheid ten opsigte van dít in die gemeente wat nie tot die eer van God strek nie (teks in Pont 1981:27). Vir die eerste meerdere vergadering of gesamentlike vergadering van gemeentes in die Nederlandse gereformeerde tradisie, die Konvent van Wezel in 1568, is dit 'n uitgemaakte saak: die leraar(s) en ouderlinge moet lidmate van 'huis tot huis' besoek. Hierdie besoeke moet weekliks plaasvind, maar veral rondom nagmaal in die gemeente (teks in 1.Vorster skryf waarskynlik die eerste vier van ses hoofstukke en redigeer die res (Langner 2007:87). 
Biesterveld \& Kuyper 1905:8, 16-17). Hoewel die Nasionale Sinode van Middelburg in 1581 huisbesoek nie eksplisiet as 'n ampsopdrag aan die leraar(s) toesê nie, bly hierdie taak in die destydse Gereformeerde Kerk in Nederland van krag (Kleynhans 1988:106). DKO artikel 16 loop dieselfde ongespesifiseerde pad met sy opdragte aan die predikant. Die ouderlinge is saam met die bedienaar(s) van die Woord verantwoordelik vir die opsig en tug oor gemeentelede én daarom, Wezel bepaal dit, ook vir huisbesoek. Die taak van die ouderling word vervat in DKO artikel 23 (teks in Pont 1981:178-179).

Om te kwalifiseer as 'Die DKO aangepas by die eise van die dag' vorm NGKO 1962 nie 'n totaal nuwe NGKO nie. Inteendeel, op 'n besluit van die Federale Raad van Nederduitse Gereformeerde Kerke in 1957, gebruik en hersien NGKO 1962 die Kerkorde van die Gereformeerde Kerke in Nederland van 1959 (afgekort as GKN-KO 1959) as die voorbeeld waarop hy werk. Hierdie Kerkorde, so het die NGK aanvaar, volg die hooflyne en hoofstukindeling van die DKO, maar vir sy eie tyd (NGK 1957:73-74; Langner 2007:87). Gevolglik kom sekere formulerings in NGKO 1962 feitlik net so uit GKN-KO 1959. GKN-KO 1959 plaas die artikels wat daaronder hoort onder 'Het werk van de kerk' in sy hoofstuk III, terwyl NGKO 1962 dieselfde soort artikels in hoofstuk IV onder die opskrif 'Die arbeid van die kerk' opneem (Nauta 1971:239; NGKO 1964:10). Die opskrif ‘Die herderlike sorg' vir NGKO 1962 artikel 51 ontleen hy aan die opskrif vir GKN-KO 1959 artikel 82. In NGKO 1962 artikel 51 weerklink ook talle verwoordings van GKN-KO artikel 82 oor die herderlike sorg. NGKO 1962 kry sy uitdrukking 'herderlike sorg' boonop netso uit GKN-KO 1959 (Nauta 1971:288; NGKO 1964:11).

GKN-KO artikel 82 gee oor herderlike sorg bepalings vir huisbesoek deur die ampte. Die woord 'huisbesoek' kom nie in GKN-KO artikel 82 voor nie, maar as GKN-KO artikel 24 na die taak van die ouderling verwys, koppel hy herderlike sorg direk aan 'de (indiwiduele) leden der gemeente trouw te bezoeken...' (Nauta 1971:103, 288). Volgens artikel 82 rig herderlike sorg hom tot alle lidmate van die gemeente. Hierdie herderlike sorg wat nadruklik getrou bedien moet word, word aan die leraars en ouderlinge toevertrou. Die sorg moet in besonder uitreik na die siekes en bejaardes wat nie meer in die kerk kan kom nie, asook aan afgedwaaldes. Lidmate moet tot 'n lewende geloof opgewek word, in teenspoed getroos word en van dwalings, 'n wêreldse wandel en goddelose praktyke weerhou word (Nauta 1971:288).

Nauta (1971:289-292) wys daarop daarop dat GKN-KO artikel 82 se verwoording van herderlike sorg grotendeels 'n uitbreiding en verbetering van 'de oude', meer letterlik Dordtse GKN-KO is. Herdelike sorg as 'n term kom ook nie in die ou Kerkorde voor nie (Jansen 1952:74-78), terwyl dit 'n gepaste benaming en Skriftuurlike metafoor vir die geestelike taak van ampsdraers is. Om herderlike sorg in soveel woorde as die taak van die kerk in GKN-KO 1959 op te neem, was 'n winspunt. GKN-KO koppel die taak van herderlike sorg, sonder om 'n onderskeid ten opsigte van die lading daarvan te maak, aan beide die leraar(s) en die ouderlinge.

In sy bespreking van huisbesoek as herderlike sorg - Nauta hanteer huisbesoek as die eerste punt wat onder herderlike sorg aan die orde kom - beperk Nauta (1971:289-292) hom 'tot de direct kerkordelijke aspecten er van'. Daarom gaan hy aan die tyd en inrigting van die huisbesoek verby. Hy onderskei tereg tussen, wat hy noem, die tegniek van huisbesoek en die kerkordelike kante daarvan. ${ }^{2}$

Die eerste saak in GKN-KO artikel 82 wat Nauta (1971) uitwys, is getrouheid in die besoeke. Getrouheid staan teenoor 'n af en toe of 'n terloopse besoek. Getrouheid verbind die besoek tot 'n behoorlike geestelike versorging van die besoekte(s). GKN-KO skryf nie die frekwensie van hierdie besoeke voor nie, maar getrouheid beklemtoon die erns daarvan. Dit is 'n noodsaaklike besoek met tasbare geestelike versorging deur'n herder van die kudde as die oogmerk.

Nauta (1971:289-292) merk op dat GKN-KO 1959 in sy artikel 82 meer uitgebreid as DKO 1619 wys op hulle wat besoek moet word. Die rede vir die groepe wat hier genoem word, naamlik siekes en oues, is hulle feitelike onvermoë om Sondae by die kerk uit te kom. Nauta (1971) noem hierdie groepe egter voorbeelde wat die kerk sensitief moet maak vir spesiale gevalle wat besoeke nodig het. Anders gestel: huisbesoek gaan oor die versorging van 'n familie of indiwidu of kleingroepe met'n bepaalde agtergond. Die aard en inhoud van die besoek moet hiermee rekening hou en die boodskap en gebed daarop gerig wees.

Getrou aan sy uitgangspunt as gereformeerde, oordeel Nauta (1971) dat herderlike sorg in sy kern 'altijd' moet bestaan uit die bring van die Woord van God. Die Evangelie van Christus moet in die sentrum van die versorging staan. ${ }^{3}$ Die Woord moet met die oog op die omstandighede of eie konteks waarin lidmate verkeer, gebring word. Dit gaan hier om 'n persoonlike element wat by huisbesoek 'in sterke mate moeten uitkomen'. Spoelstra (1989:112) voeg hieraan toe dat die bedienaar van die Woord met huisbesoek 'n ampsgetroue leraar moet wees wie se werk op die verkondiging van die waarheid van Gods Woord in die omstandighede afgestem is.

Die afgedwaaldes moet met noulettendheid benader word. Hulle mag nie aan hulle 'lot' oorgelaat word nie en bly voorwerpe van die kerklike bediening. Hulle moet sover moontlik na die kudde teruggebring en weer daarin opgeneem word. Volgens Nauta (1971) is GKN-KO artikel 82 se opwekking tot 'n lewende geloof en troos in teenspoed vanselfsprekend. Daarby word die Christelike geloof vandag ondermyn en is valse leringe en dwalinge nie dinge van die verlede nie. 'n Wêreldse wandel en goddelose praktyke speel dikwels ook in die kerk af (Nauta 1971:291).

2.Vergelyk Haitjema (1951:274) wat die taak van'n kerkorde sien as om die kerk te beveilig teen dwalinge wat die fondamente van die kerk aantas. Nauta (1971:9) gebruik dieselfde begrip.

3.Strauss (2010:29) wys op die stelling dat Christusgesag Woordgesag is en dat dit genoeg vir'n gesonde kerklike lewe is. 


\section{Geskiedenis van die Kerkorde van die NGK artikel 51}

Hoewel NGKO 1962 op GKN-KO 1959 as sy direkte voorbeeld steun, toon NGKO 1962 artikel 51, teenoor GKN-KO artikel 82 , ook elemente van 'n eie koers wat ingeslaan word.

NGKO 1962 artikel 51 ontleen sy opskrif 'Die herderlike sorg' aan GKN-KO 1959. Soos GKN-KO 1959 artikel 82 gebruik NGKO 1962 artikel 51 hierdie woorde as dekkende terme vir sy bepalings oor huisbesoek deur die ampte aan alle lidmate van die gemeente. Bloot op die klank af is 'herderlike sorg' 'n plegtiger en deftiger uitdrukking as 'huisbesoek'. Tog sal die gemiddelde lidmaat, waaronder talle predikante, die saak waaroor NGKO 1962 artikel 51 handel, onmiddellik met die bekende en historiese 'huisbesoek' in verband bring. NGKO 1962 artikel 51 val weg (NGKO 1964:11) met die kort en saaklike bepaling dat die ampte 'deur getroue huisbesoek hulle herderlike sorg uitstrek tot alle lidmate van die gemeente'. Huisbesoek is vir NGKO 1962 artikel 51 'n vorm van herderlike sorg en 'n integrale deel van die ampswerk van die drie besondere ampte. Die begrip 'getroue huisbesoek' stem ooreen met Nauta (1971:290) se opvatting van gehaltebesoeke wat deur 'getrouheid' op 'n sinvolle vlak geplaas word. Getroue huisbesoek impliseer die erns en noodsaak van die besoek. Soos alle kerklidmate gereeld by eredienste en die amptelike bediening van die Woord as deel van hulle lidmaatskap en lewe van dankbaarheid moet uitkom, so moet die ampdraers gereeld by alle 'amptelike' of boeklidmate van die gemeente uitkom. Dit gaan in beide gevalle - erediens en huisbesoek - om die regering van die Woord en Gees van God in die hele kerk en samelewing. ${ }^{4}$ Die gehoorsaamheid van die kudde aan die Woord beteken ook gehoorsaamheid aan die Hoof van die kerk, Jesus Christus (Jonker 1965:6). Deur hierdie besoeke nie net aan die predikant en ouderling as lerende en regerende ouderlinge te koppel nie, maar ook aan die diaken, impliseer NGKO 1962 dat die Woord direk én indirek sentraal moet staan in elke amptelike besoek. As Hoof van sy kerk staan Christus immers sentraal in die bediening van hierdie kerk. En, Hy regeer sy kerk deur sy Woord en Gees (Strauss s.a.:16-20). Ook hier waar dit gaan oor die versorging van armes of siekes of die weerspreking van 'n saak wat nie tot eer van God strek nie. Goeie herderlike sorg in alle materiële en geestelike nood gebruik die Woord as rigtinggewende herderstaf (Strauss 2010:61).

NGKO 1962 artikel 51 (NGKO 1964:11) sonder groepe uit by wie 'in besonder' uitgekom moet word: behoeftiges of mense in een of ander nood, siekes en oues van dae. Die indiwidualisering van sulke besoeke blyk uit die opdrag dat die besoektes bemoedig, vertroos en ondersteun moet word. Daar moet by hulle persoonlik of by hulle harte uitgekom word. Hierdie beginsel en die voorbeelde moet ampsdraers sensitief maak vir die behoeftes van indiwidue en kleingroepe in die gemeente. 'n Persoonlike woord van 'n herder gebaseer op Gods Woord en 'n gebed vol vertroue én hoorbaar vir diegene in nood vir wie daar by God ingetree word, hou onberekenbare geestelike wins in.

NGKO 1962 artikel 51 leen dus duidelik by GKN-KO artikel 82. Tog toon dit ook tekens van onafhanklike denke.

Anders as GKN-KO 1959 beperk NGKO 1962 diegene wat die besoeke aflê nie tot die predikant(e) en ouderlinge nie. Al drie die besondere ampte moet indiwiduele nood en behoeftes ten diepste vanuit die Woord as 'n instrument van Christus hanteer. Daarom is huisbesoek vir NGKO 1962 'n opdrag aan die 'bedienaars van die Woord, ouderlinge en diakens', nie net aan eersgenoemde twee ampte soos by GKN-KO nie. Hierdie bepaling verhoed natuurlik nie dat elke amp tydens huisbesoek 'n eie invalshoek, eie aan die aard van die amp, gebruik en dat lidmate 'n behoefte aan elkeen spesifiek kan toon nie (Kleynhans 1988:109, 1991:86). Die begrippe behoeftiges, siekes en oues van dae toon duideliker as GKN-KO wat die groepe tot die siekes en oues beperk, dat hier voorbeelde van mense in nood is sonder dat die lys beperk word: daarom die algemene begrip 'behoeftiges'. Die waarskuwings teen valse leringe, dwalinge, 'n wêreldse gesindheid en goddelose lewenspraktyke stem opmerklik ooreen met GKN-KO artikel 82 en behoef geen verduideliking of motivering nie. Genoeg om te sê dat NGKO, soos GKN-KO, hiermee die gereformeerde antitese tussen Christelik en nie-Christelik op elke terrein van die lewe handhaaf en die kerk aanmoedig om sy profetiese stem in die gemeenskap te laat hoor (Strauss 2010:125-130). Volgens NGKO 1962 moet lidmate, in besonder die behoeftiges, siekes en oues, bemoedig, vertroos en ondersteun word. Die bemoediging ondervang GKN-KO se opwekking tot 'n lewende geloof, troos is 'n beproefde harnas teen teenspoed en ondersteuning mik téén dwalinge op 'n lewende geloof en 'n gehoorsame lewenswandel.

Teen 1962 is die kwessie van huisbesoek deur die ampte 'n ou kwessie in die NGK. 'n Saak wat reeds vroeër by die Sinodes wat in 1962 in een algemene sinodale verband verenig, voor gekom het. So gee die Sinode van 1842 van die NGK in SuidAfrika (die Kaapse Sinode) aan predikante kerkordelik die opdrag om 'behoorlijk godsdienstige huisbezoeking te doen' (Kleynhans 1988:107). Huisbesoek gaan dus uitdruklik oor godsdienstige aangeleenthede en nie gemeenplase of koeitjies en kalfies nie. Huisbesoek moet volgens die Sinode van 1842 'n egte kerklike aktiwiteit van die kerk as 'n Christelike geloofsverband wees. Op sy beurt praat die Kaapse Sinode van 1873 van huis- en siekebesoek as herderlike sorg en deel van die ampspligte van die herder en leraar (Kleynhans 1988:107). Dieselfde Sinode gee huisbesoek en daarmee toesig oor die gemeente ook as opdrag aan die ouderling (Kleynhans 1988:107). Daarmee toon die NGK, soos later in NGKO 1962, sy affiniteit vir die Dordtse tradisie met amptelike 'huisbezoeking'.

Opgesom bepaal NGKO 1962 artikel 51 dat die besondere kerklike ampte van predikant, ouderling en diaken huisbesoek en dus herderlike sorg by alle lidmate doen. 
Dit gaan 'in besonder' oor behoeftiges wat die siekes en oues van dae insluit. Dat hierdie sorg of besoeke van 'n Woordgerigte en 'n geestelike aard moet wees, blyk uit die doel daarvan: lidmate moet bemoedig, vertroos en ondersteun én teen dwalinge en nie-Christelike gesindhede en lewenspraktyke gewaarsku word (NGKO 1964:11).

\section{Die Kerkorde van die NGK artikel $\mathbf{5 1}$ meer as $\mathbf{5 0}$ jaar konstant}

Behalwe vir 'n geringe redaksionele wysiging in 1990, sou NGKO 1962 artikel 51 tot in 2011 inhoudelik dieselfde bly. 'n Konstantheid wat, te midde van 'n gedurige wysiging van artikels van NGKO deur opeenvolgende Algemene Sinodes, byna 50 jaar gehandhaaf word! 5

Die Algemene Sinode van 2011 voeg twee artikels onder die opskriffie 'Die herderlike sorg' by NGKO artikel 51. Die bestaande artikel 51 word artikel 51.1. 'n Nuwe artikel 51.2 bepaal dat 'die Christelike huwelik' as 'n instelling van God heilig gehou moet word en dat kerkrade hieroor herderlik moet waak. Daarby bepaal 'n nuwe NGKO artikel 51.3 dat kerkrade moet toesien dat afgestorwe lidmate op "n Christelike wyse' begrawe of veras word (NGKO 2011:15, vgl. NGKO 2015:15).

Die vraag is waarom NGKO artikel 51 solank dieselfde gebly het.

Die mees vanselfprekende antwoord hierop - uit 'n tipies kerklike hoek - is dat hierdie bepaling van die NGKO nie omstrede is nie en 'n waarheid en praktyk aansny waarsonder NGK-gemeentes nie kan nie en nie wil nie. Dat die herderlike noodsaak van huisbesoek en pastorale sorg in die NGK vanuit 'n breë konsensus onder NGK-kerkrade en -gemeentes onderstreep en deur die ampte nagejaag word. Dat hierdie artikel in NGKO so lank so gebly het omdat die inhoud daarvan in die NGK' $n$ aanvaarde, beproefde praktyk is. Dat die NGK, as 'n 'nederduitse' gereformeerde kerk wat spruit uit die landing van Jan van Riebeeck aan die Kaap in 1652 én uit die sinodale geskiedenis van die Gereformeerde Kerk in Nederland, daarom ook daarvan oortuig is - soos die Friese Sinode van 1652 - dat'n versuim van huisbesoek ampsversuim en dus tugwaardig is.

Dit is moeilik om 'n hand op die statistiek oor amptelike huisbesoek (huisbesoek deur die ampte) in NGK-gemeentes te lê. Die totaalindruk is egter dat huisbesoek deur die ampte in NGK-gemeentes nie oral tot sy reg kom nie en aan die afgeskeep word. Dat min of geen huisbesoek nie sommer by kerkvisitasieverslae deur ringe as ampsversuim uitgelig word nie. 'n Gebrek aan huisbesoek deur die dominee in 'n NGK-gemeente as 'n voorbeeld van ampsversuim is $\mathrm{n}$ vreemde begrip wat nie sommer op kerkvergaderings gehoor word nie. Die vraag na huisbesoek deur die ampte is ook nie 'n vraag wat normaalweg tydens kerkvisitasie opduik nie.
Gebeur dit wel, word verskeie redes vir 'n gebrek aan huisbesoek - en daarmee die herderlike sorg van alle lidmate so asof terloops opgerakel. Dit word egter nie deurtastend bespreek of die probleme daarvan ondersoek én die prioriteit en regstelling daarvan à la NGKO artikel 51 bepaal nie. Huisbesoek ly skynbaar onder die verdwyning van gemeentegrense in die huidige praktyk; die probleem om die lidmaat op sy/haar plek van domisilie vas te pen vir so 'n besoek; gebrekkige ampsgesag en die ontbreking van 'n roeping daarvoor by ampsdraers; die onbybelse, inwidualistiese smake van lidmate teenoor die sogenaamde 'kerk'; en die belangelose traak-my-nie-agtige inrigting van die besoek (Strauss 2008:242).

Daarby kry die toepassing van NGKO artikel 9, wat aandui dat die bedienaar van die Woord 'saam met die ander ampte' verantwoordelik is vir die pastorale versorging van die gemeente, nie die aandag wat dit verdien nie (NGKO 2015:4). Die resultaat van 'n voortdurende evaluering van pastorale sorg in die gemeenteas'n onderdeel van die 'diensooreenkoms' van die predikant en kerkraad kan verhoudinge op die kerkraad versteur ... Lidmate, ampsdraers (ook dominees) en selfs gemeentes wil nie voorgesê of vermaan word nie (Kleyn \& Viljoen 1988:267vv; Strauss 2010:109). Die tradisionele lees en bid - hoe voorbereid, ter sake en pastoraal dit ook al mag oorkom - is vir hulle nie 'n prioriteit of noodsaaklik vir die daaglikse lewe nie.

\section{Die huwelik en begrafnis herderlik begelei}

Anders as DKO 1619 en GKN-KO 1959 bevat NGKO 1962 geen artikel oor die kerk se rol teenoor die huwelik en huweliksluiting nie. Hierin kom daar by die Algemene Sinode van 2011 'n verandering. 'n Verandering wat egter nie na een van bogenoemde Kerkordes wat NGKO 1962 voorgegaan het nie, herlei kan word nie.

NGKO 2011 artikel 51.2 bepaal dat die 'Christelike huwelik as 'n instelling van God' - dit is die roeping van alle getroudes in die gemeente - 'heilig gehou' moet word en dat kerkrade hieroor die 'nodige' herderlike toesig moet hou (NGKO 2011:15). Hiermee maak NGKO 2011 oor die huwelik as deel van die omvattende Christelike of gehoorsaamheidslewe voor God 'n uitsondering.

In kerkordelike terme beteken dit dat NGKO na bykans 'n halfeeu hom aansluit by gereformeerde kerke in die Dordtse tradisie wat in hulle kerkordes wel by die huwelik uitkom. In teenstelling met ander kerkordes wat op die kerk se aandeel aan huweliksluiting konsentreer (Kruger et al. 1966:412-414), konsentreer NGKO artikel 51.2 egter op die kern van die saak: die huwelik as 'n instelling van God moet heilig gehou word deur die Bybels Christelike norme daarvoor te eerbiedig én kerkrade moet hierin op lidmate ag gee. Die huwelik is deel van die Godgehoorsame lewe waarin die gelowige op die eer van God ingestel moet wees. Daarom is kerkrade daarby betrokke (NGKO 2015:15). NGKO 2015 bevat immers 
ook die bepaling dat die kerklike opsig oor die 'hele lewenswandel' van doop- en belydende lidmate (daarom ook ampsdraers) strek (NGKO 2015:17). NGKO 2011:15, soos oorgeneem in NGKO 2015:15, verklaar dus opnuut dat die huwelik as 'n instelling van God heilig is en dat kerkrade met herderlike sorg daarna moet omsien.

Teenoor NGKO 2015 artikel 51 handel DKO 1619 in sy artikel oor 'huwelijks-ordonnantiën' egter oor die reëlings vir die sluiting van 'n huwelik waarby die Nederlandse staatsowerheid betrek moet word. Getrou aan die beginsels van die Reformasie erken DKO 1619 by implikasie dat die staatsowerheid na sy eie aard 'n regsoorgaan is wat aan die sluiting van 'n huwelik regskrag verleen -'n punt waarsonder die kerk nie by magte is om huweliksluiting af te handel nie. Omdat hyself daarby betrokke is, versoek die Gereformeerde Kerk sy owerheid in Nederland om 'n algemene huweliksordonnansie daar te stel waarin alle kerke hulle tuisvind en huwelike 'conform Gods Woord' en 'kerklijke ordonnantiën' kan inseën. 'n Inseëning wat die staatswet eerbiedig wat die geldigheid en regskante van die sluiting van huwelike reël en op so 'n sluiting moet volg. Die kerk kan immers nie'n huwelik wat nie wettig gesluit is en nie deur die staat as die algemene regsorgaan in die samelewing erken word, inseën nie. Binne die Nederlandse gemeenskap is so 'n handeling 'n gejaag na wind (teks by Pont 1981:184; volgens De Klerk 1982:112,114-115; Trimp 1983:247-250 oor die rol van kerk en staat by huweliksluiting of -bevestiging).

Met sy ingeseënde huwelike ooreenkomstig Gods Woord volg DKO 1619 dieselfde breë lyn as NGKO 2011 artikel 51 met sy 'heilige huwelik' wat deur God ingestel is. Die omstandighede waarin hulle die bepaling maak, verskil egter. Waar DKO 1619 'n ordonnansie van die staat vra wat eenvormigheid in die wettige sluiting van huwelike reël, bevind NGKO 2011 hom in 'n wêreld waarin die Christelike huwelik onder groot druk is en egskeidingsyfers die hoogte in geskiet het. Tipies van gereformeerde kerkordes is beide DKO en NGKO in hulle bepalings eietyds en relevant gerig op die omstandighede waarin hulle die kerk in sy taak moet dien (Strauss 2010:1-6, 15-20). Wat ook waar is, is dat NGKO 2011 ten opsigte van hierdie faset van herderlike sorg 'n eie, prinsipieel aanvaarbare koers inslaan.

In 'n nuwe artikel 51.3 kom NGKO 2011 met 'n herderlike woord oor begrafnisse.

Teen die agtergrond van NGKO 1962 se gebruik van GKNKO 1959 as sy direkte voorbeeld, vertoon die nuwe NGKO 2011 artikel 51.3 oor begrafnisse 'n nuwe benadering tot die hersiening van NGKO in die jare ná 1962. Teenoor 'n vrye wysiging van NGKO wat GKN-KO 1959 en DKO 1619 ná 1962 nie meer in berekening sou bring nie, toon NGKO 2011 artikel 51.3 opnuut wesenlike ooreenkomste met GKN-KO 1959 artikel 87 (vgl. Nauta 1971:305; NGKO 2011:15).

In 'n land waarin gebrekkige dienslewering by die massa groot weerstand wek en die versorging van begraafplase en afgestorwenes een van die terreine is waaroor daar vraagtekens hang, bevat NGKO 2011 vir die eerste keer sedert die ontstaan van die NGKO in 1962 'n bepaling vir begrafnisse. NGKO 2011 artikel 51.3 versoek kerkrade om toe te sien dat afgestorwe lidmate van die gemeente 'op 'n Christelike wyse' begrawe of veras word. Voor 2011 is hierdie aangeleentheid in die reël deur kerklik aanvaarbare gebruike bepaal wat meegebring het dat die NGKO daaroor kon swyg. Die oprigting van gedenkmure - ook by kerke waar mense juis jare gelede begrawe is - met plek vir nissies met die as van gestorwenes en die groot toename in verassings wat albei 'n beter versorging van die reste van die dooies meebring, het verskuiwings veroorsaak wat tot nuwe gebruike by begrafnisse gelei het. Die tradisionele begrafnis of letterlike teraardebestelling word in die proses vervang deur 'n verassing wat tot 'n meer beskermde en beheerde versorging van die asse/ oorblyfsels ná die 'bêre' daarvan lei. Wat vroeër 'Bybelsgebaseerde' weerstand en debat ontlok het, het nou 'n aanvaarde gebruik of gewoonte geword. Vrae oor die wenslikheid daarvan het met die koms van nuwe omstandighede en gebruike verdwyn.

Gevolglik bepaal NGKO 2011 artikel 51.3 dat kerkrade moet 'kerklik-aanvaarbare' dat afgestorwe lidmate 'op 'n Christelike wyse begrawe/veras word'. Hoewel 'n begrafnis nie 'n suiwer kerklike aangeleentheid nie, maar meer 'n indiwiduele en familiesaak is (De Klerk 1982:116; Nauta 1971:307), gee NGKO 2011 tog hierdie opdrag aan kerkrade in 'n nuwe situasie. Naas 'n begrafnis in 'n kis erken die NGK verassing kerkordelik. Die oogmerk daarvan is bes moontlik klarigheid vir gelowiges onder die nuwe omstandighede. Soos in sy bepaling oor die huwelik, is NGKO artikel 51 hier syns insiens Woordgetrou én eietyds.

GKN-KO 1959 artikel 87 bepaal ook dat kerkrade daaraan meewerk dat afgestorwe gemeentelede 'op christelijke wijze begraven worden' (Nauta 1971:305). Met hierdie woorde het GKN-KO 1959 - was dit profeties? - na die smaak van die Algemene Sinode van die NGK van 2011 by sy vasstelling van NGKO 2011 gespreek.

In die kern van die saak gebruik NGKO 2011 byna dieselfde formulering as GKN-KO 1959. In GKN-KO 1959 artikel 87 moet kerkrade meewerk dat afgestorwe lidmate op 'n Christelike wyse begrawe word en in NGKO 2011 artikel 51.3 moet hulle toesien dat dieselfde gebeur. 'Toesien' beteken die reële bepaling van die Christelike wyse, terwyl 'meewerk' doelbewus eerbied vir die omstandighede en gebruike van die bepaalde geval, familie of plek impliseer (Nauta 1971:306). In sy kommentaar op GKN-KO 1959 artikel 87 bepleit Nauta (1971:307-308) kerkdienste - nie gemeentelike eredienste nie - by Christelike begrafnisse met Woordverkondiging en gebede van troos en bemoediging waarin die klem val op die Here Jesus, wat deur sy opstanding en geloof in sy opstanding die ewige lewe waarborg. Ten opsigte van die oorledene moet woorde - in die preek of toesprake van eerbetoon - by hierdie geleentheid 
nie lofredes word nie, maar gerig wees op sy/haar betoonde nuttigheid vir die Koninkryk van God hier op aarde. Nauta (1971:307-308) koppel GKN-KO aan die sobere begrafnisgebruike en hartseer van Christengelowiges, omdat gereformeerdheid soberheid met eerbied vir God in verband bring. Omdat die Bybel volgens Nauta (1971:307308) nie duidelike uitsprake daaroor maak nie, kan verassing of 'crematie' in sy tyd kerklik verdra en as 'n keuse van gemeentelede eerbiedig word. 'n Saak wat sonder 'n omhaal van woorde in NGKO 2011 geformuleer en as toelaatbaar beskou word. 'n Kerkraad en predikant wat op hierdie punt van lidmate verskil, kan nie daarom hulle meewerking aan die begrafnis weerhou nie (Nauta 1971:307-308). Wat opval, is dat GKN-KO 1959 speelruimte aan die begrafnis as 'n familiesaak gee en daarom in artikel 87 praat van die kerkraad se meewerking in plaas van die kerkraad wat bepaal. Hierteenoor impliseer NGKO 2011 en sy opvolgers dat die Christelike wyse van 'n begrafnis kerklik gereël en breedweg in sinodaal goedgekeurde handboeke vir die liturgie en die volgordes van dienste bepaal word (Strauss 2013:77-78; vgl. NGK-ADGO 2010:1vv). Sinodes van die $16 \mathrm{e}$ eeu in die Gereformeerde Kerk in Nederland het lykpredikasies, 'n Roomse verskynsel wat neerkom op lofredes vir die afgestorwene wie se lyk ook in die kerk vertoon word, afgeskaf. Die lui van kerkklokke om die bose geeste te verdryf, asook gebede vir die oorledenes het dieselfde paadjie geloop (Jansen 1952:284).

\section{Slot}

Gegrond op Skriftuurlike konstantes wat handel oor die herderlike versorging van die lidmate van die gemeentes as die kudde van die Here God deur ampte, beskou gereformeerde kerke huisbesoek as die Woordgedrewe, toegespitste versorging van indiwidue, kleingroepe of gesinne as uiters belangrik. Gevolglik plaas NGKO 2011 artikel 51 huisbesoek saam met bepalings oor die Christelike aard van huwelike en begrafnisse, onder 'Die Herderlike sorg'. Herderlike sorg, aldus die NGKO, mik op die herstel of welsyn van die Christelike lewenstyl van lidmate. Herderlike sorg versorg met die Woord om 'n lewensomvattende gehoorsaamheid aan God by lidmate te bevorder.

Daarby skep getroue en gehaltehuisbesoek die moontlikheid van 'n groter persoonlike belewenis van en deelname aan die gemeente by lidmate: 'n prinsipiële aspek van moderne gemeentewees vir herder en gemeentelid. Huisbesoek of persoonlike kontak met die gemeente kan vir die bedienaar van die Woord ook paslike terugvoer op sy bediening, waaronder sy/haar preke, bring.

In NGKO 2015 word herderlike sorg nie soos in ou Nederlands gereformeerde kerkordes tot die predikant en ouderling beperk nie. Die amptelike, persoonlike versorging van alle lidmate, al sou dit in 'n bepaalde geval op die versorging van materiële nood neerkom, moet ook herderlik én daarom geestelik versorgend wees.
Die lidmate saam of indiwidueel as die kudde van die Here God op 'n bepaalde plek en waarvoor Hy ampsdraers vir hulle toegesegde taak as herders roep, bly in moderne tye in kerk- en gemeentewees belangrik.

\section{Erkenning Mededingende belange}

Die outeur bevestig dat hy geen mededinginge belange het nie.

\section{Outersbydrae}

P.J.S. was die enigste outeur betrokke by die skryf van die artikel.

\section{Etiese oorwegings}

Hierdie artikel voldoen aan alle etiese standaarde vir navorsing sonder direkte kontak met mens of dier.

\section{Befondsing}

Hierdie navorsing het geen spesifieke toekenning ontvan van enige befondsingsagentskap in die openbare, kommersiële of nie-winsgewende sektore nie.

\section{Data beskikbaarheidsverklaring}

Data-deling is nie van toepassing op hierdie artikel nie, aangesien geen nuwe data in die studie geskep of ontleed is nie.

\section{Vrywaring}

Die sienings en menings wat in hierdie artikel uitgedruk word, is dié van die outeur en weerspieël nie noodwendig die amptelike beleid of posisie van enige geaffilieerde agentskap van die outeur nie.

\section{Literatuursverwysings}

Barnard, A.C., 1989, Die erediens, NG Kerkboekhandel Transvaal, Pretoria. Biesterveld, P. \& Kuyper, H.H., 1905, Kerkelijk Handboekje, Bos, Kampen.

Bouwman, H., 1985, Gereformeerd Kerkrecht I, 3de onveranderde druk, De Groot Goudriaan, Kampen.

De Klerk, J.J., 1982, Liturgiese grondlyne, NG Kerk-Uitgewers, Kaapstad.

Haitjema, T.L., 1951, Nederlands Hervormd Kerkrecht, Callenbach, Nijkerk.

Jansen, J., 1952, Korte verklaring van de Kerkorde der Gereformeerde Kerken, Kok, Kampen.

Jonker, W.D., 1965, Om die regering van Christus in sy kerk, Unisa, Pretoria.

Kleyn, D. \& Viljoen, F., 1999, Beginnersgids vir regstudente, 2 de druk, Juta, Kenwyn.

Kleynhans, E.P.J., 1988, Gereformeerde Kerkreg IV, NG Kerkboekhandel Transvaal, Pretoria.

Kleynhans, E.P.J., 1991, 'Die drie besondere ampte nog houdbaar?', in P.J. Strauss (red.), Byderwets en gereformeerd, bl. 77-89, Pro Christo, Bloemfontein.

Kruger, L.S., Du Plessis, H.L.M., Spoelstra, B. \& Spoelstra, T.T., 1966, Handleiding by die kerkorde, Pro Rege, Potchefstroom.

Langner, D., 2007, Teen die hele wêreld vry-Koot Vorster, segsman of profeet?, Griffel, Pretoria.

Nauta, D., 1971, Verklaring van de Kerkorde van de Gereformeerde Kerken in Nederland, Kok, Kampen.

Nederduitse Gereformeerde Kerk (NGK), 1957, Handelinge Raad van Kerke, s.n., s.I.

Nederduitse Gereformeerde Kerk (NGKO), 1964, Kerkorde van die Ned Geref Kerk 1962, NG Kerk-Uitgewers, Pretoria. 
Nederduitse Gereformeerde Kerk (NGKO), 2011, Die Kerkorde van die Ned Geref Kerk, s.n., s.l.

Nederduitse Gereformeerde Kerk (NGKO), 2015, Die Kerkorde van die Ned Geref Kerk, s.n., s.l.

Nederduitse Gereformeerde Kerk Algemene Diensgroep Gemeente-ontwikkeling (NGK-ADGO), 2010, Handleiding vir die erediens, Bybelmedia, Wellington.

Pont, A.D., 1981, Die historiese agtergronde van ons kerklike reg I, HAUM, Pretoria.

Spoelstra, B., 1989, Gereformeerde kerkreg en kerkregering, Teologiese Skool van die Gereformeerde Kerke in Suid-Afrika, Hammanskraal.

Strauss, P.J., 1997, 'Die krisis rondom "meerdere" vergaderings in die Ned Geref Kerkenkele aantekeninge en raakpunte met teologiese opleiding', Ned Geref Teologiese Tydskrif 38(3), 171-179.
Strauss, P.J., 2008, 'Die "kerklike gesag" van kerkvergaderings soos in die Kerkorde van die Ned Geref Kerk', In die Skriflig 42(2), 239-252. https://doi.org/10.4102/ids. v42i2.266

Strauss, P.J., 2010, Kerk en orde vandag. Met die klem op die NG Kerk, SUN MeDIA, Bloemfontein.

Strauss, P.J., 2013, 'Kerkwees in die branding. Die Nederduits Gereformeerde Kerk in algemene sinodale verband 1994-2011', Acta Theologica Supplementum 18 1-154. https://doi.org/10.4314/actat.v33i1S.1

Strauss, P.J., 1995, Die Gees werk soos Hy wil.., VCHO, Bloemfontein.

Trimp, C., 1983, De gemeente en haar liturgie, Van den Berg, Kampen.

Vorster, J.D., 1960, 'Die kerkorde van die Ned Geref Kerke: Besware daarteen en betekenis daarvan', Ned Geref Teologiese Tydskrif (NGTT) 1(4), 12-18. 